\title{
IPTEKS Bagi Masyarakat Kelompok Pembudidaya Lobster
}

\author{
Muhammad Junaidi ${ }^{1}$, Ayu Adhita Damayanti ${ }^{1}$, Bagus Dwi Hari Setyono, Nunik Cokrowati ${ }^{1 *}$ \\ ${ }^{1}$ Jurusan Perikanan dan Ilmu Kelautan, Fakultas Pertanian, Universitas Mataram, Mataram, Lombok, Nusa Tenggara Barat, Indonesia.
}

\section{Article Info}

Received: November 22th $2020 \quad$ Revised: December 27th, $2020 \quad$ Accepted: December $30^{\text {th }}$, 2020

\begin{abstract}
Abstrak: Meningkatnya permintaan komoditas lobster menyebabkan permintaan benih lobster juga terus meningkat. UD Sari Laut sebagai kelompok pembudidaya lobster mengalami kesulitan untuk memenuhi permintaan lobster karena terbatasnya Karamba Jaring Apung (KJA) untuk melakukan usaha pendederan benih lobster. Usaha budidaya lobster yang intensif, diperkirakan sekitar $70 \%$ biaya produksi berasal dari biaya pakan. Tujuan kegiatan ini adalah melakukan penerapan teknologi penangkapan ikan rucah menggunakan bagan apung untuk meningkatkan skala usaha budidaya lobster, dan mengurangi biaya pengadaan pakan. Metode kegiatan yang digunakan adalah demplot secara langsung bersama mitra kegiatan dengan tahapan kegiatan meliputi persiapan pengadaan Karamba Jaring Apung (KJA) dan bagan apung, pelatihan kelompok, pembinaan, monitoring dan evaluasi. Hasil kegiatan ini adlah penambahan petak KJA menjadi 9 petak yang sebelumnya hanya 6 petak memberikan nilai positif bagi UD Sari Laut. Selain dapat menampung sekitar 1.350 ekor benih lobster, dengan penambahan petak KJA juga dapat dimanfaatkan untuk kegiatan pendederan benih lobster dengan keuntungan sebesar Rp. 2.970.000/bulan. Hasil kegiatan pengadaan bagan apung untuk penangkapan ikan rucah untuk memenuhi kebutuhan pakan budidaya pembesaran lobster dalam KJA memberikan nilai positif bagi KUB Cinta Bahari. Dimana sebelum memiliki bagan apung, para pembudidaya biasanya membeli ikan rucah dari nelayan di sekitar lokasi. Biaya untuk membeli ikan rucah berkisar antara Rp. 30.000 - Rp 50.000, tergantung pada musim maupun skala usaha. Dengan demikian dengan beroperasinya bagan apung tersebut, biaya produksi dari pakan dapat ditekan. Adanya bagan apung ini memberikan penghasilan tambahan, dimana ikan-ikan yang memiliki nilai komersial tinggi dijual ke pasaran. Kesimpulan kegiatan ini adalah kegiatan ini memberikan nilai posisitf bagi masyarakat sasaran, dengan bertambahnya unit keramba jaring apung untuk penampungan dan pendederan benih lobster dan tersedianya karamba bagan apung.
\end{abstract}

Kata Kunci : Benih; Karamba Jaring Apung; pakan; ikan rucah; bagan

Abstract: Due to the increasing demand for lobster raw materials, the demand for lobster seeds continues to increase. UD Sari Laut as a lobster farming group is struggling to meet the demand for lobsters due to the limited number of floating net cages (In Indonesian called KJA) for running lobster seed farms. In an intensive lobster farming business, it is estimated that about $70 \%$ of production costs come from feed costs. The aim of this activity is to implement waste fishing technology using floating maps to increase the scale of lobster farming and reduce feed purchase costs. The activity method used is the demonstration plot directly with activity partners with activity stages including preparation for the purchase of floating net cages (KJA) and floating maps, group training, coaching, monitoring and evaluation. The result of this activity was the addition of KJA plots to 9 plots, previously only 6 plots giving a positive value to UD Sari Laut. Besides being able to house about 1,350 lobster seeds, with the addition of KJA plots it can also be used for lobster seed nursery operations with a profit of Rp. 2,970,000/month. The results of the garbage floating cards purchasing activity to meet the need for comprehensive lobster culture feed in KJA provides positive value for KUB Cinta Bahari. Where before having a floating card, the growers usually bought waste fish from fishermen around the site. The cost of buying waste fish ranges from Rp. 30,000 - Rp 50,000, depending on the season and the size of the business. So, with the operation of the floating card, the production cost of feed can be reduced. The existence of this floating card provides additional income, selling fish of high commercial value in the market. The conclusion of this activity is that this activity has a positive value for the target group, by increasing the number of floating net cages for the storage and breeding of lobster seeds and the availability of floating card cages.

Keywords: Benih; Karamba Jaring Apung; pakan; ikan rucah; bagan.

Citation: Junaidi, M., Damayanti, A.A., Setyono, B.D.H., \& Cokrowati, N. (2020). Ipteks Bagi Masyarakat Kelompok Pembudidaya Lobster. Unram Journal of Community Service. 1(1), 25-29. 


\section{Pendahuluan}

Lobster atau udang karang (Panulirus $s p$ ) merupakan komoditas perikanan yang potensial dan bernilai ekonomis penting untuk ekspor. Permintaan komoditas lobster, baik untuk pasar domestik maupun ekspor, terus meningkat. Susanti et al., (2017) menjelaskan bahwa pulau Lombok merupakan penghasil lobster yang di ekspor Indonesia. Pada awal tahun 2012 di Kabupaten Lombok Timur, Nusa Tenggara Barat, harga lobster di tingkat nelayan berkisar antara Rp 300.000 - Rp 350.000 per kg tergantung ukuran, jenis dan kondisi fisik lobster. Meningkatnya pasar domestik maupun ekspor, menyebabkan penangkapan komoditas lobster semakin intensif. Intensifikasi penangkapan lobster tersebut tentunya akan sangat membahayakan populasi lobster di alam. Upaya pelestarian sekaligus meningkatkan volume produksi komoditas lobster adalah melalui usaha budidaya mulai dari kegiatan pendederan dan pembesaran sampai ukuran konsumsi. Makasangkil et al., (2017) menjelaskan bahwa pakan yang dapat lebih cepat meningkatkan bobot lobter pada kegiatan pembesaran lobster yaitu pakan ikan rucah segar. Cokrowati et al., (2020) menjelaskan bahwa ikan rucah dapat juga digunakan sebagai bahan pellet moist untuk mengatasi musim ekstrim yang tidak memnugkin nelayan menangkap ikan.

Seiring dengan meningkatnya permintaan akan komoditas lobster, maka permintaan benih lobster juga terus meningkat. Usaha pembesaran lobster membutuhkan pakan yang banyak dengan biaya tidak sedikit. Pada usaha budidaya yang intensif, diperkirakan sekitar $70 \%$ biaya produksi berasal dari biaya pakan. Dengan demikian penerapan teknologi penangkapan ikan rucah dengan menggunakan bagan apung perlu dilakukan untuk meningkatkan skala usaha budidaya lobster, dan sekaligus mengurangi biaya pengadaan pakan, khususnya pembudidaya yang bergabung dalam KUB Cinta Bahari.

\section{Metode}

Metode yang digunakan pada kegiatan ini adalah demplot langsung bersama dengan mitra kegiatan. Tahapan kegiatan yang dilakukan diantaranya adalah persiapan kegiatan, pengadaan KJA dan bagan apung, pelatihan kelompok, pembinaan, monitoring dan evaluasi. Kegiatan dilakukan Desa Batunampar Kecamatan Jerowaru Kabupaten Lombok Timur. Kegiatan dilaksanakan mulai Agustus sampai dengan Desember 2012.

\section{Hasil dan Pembahasan}

Persiapan kegiatan meliputi persiapan administrasi, rapat koordinasi tim dan sosialisasi di tingkat pemerintah desa, dusun hingga ke kelompok sasaran/mitra. Rapat koordinasi dan sosialisasi program Ipteks Bagi Masyarakat (IbM) dilakukan di pemilik UD Sari Laut Desa Batu Nampar pada tanggal 31 Juli 2012, yang dihadiri Ketua Kelompok, Pemilik UD Sari Laut dan Tim IbM Kelompok Pembudidaya Lobster Air Laut.

Sebagai sarana untuk meningkatkan pengetahuan dan keterampilan kelompok masyarakat sasaran dan merupakan demonstrasi plot (demplot), maka dibangun 1 unit KJA dengan 9 petak dan 1 unit bagan apung yang di perairan sekitar Desa Batu Nampar (Gambar 1).

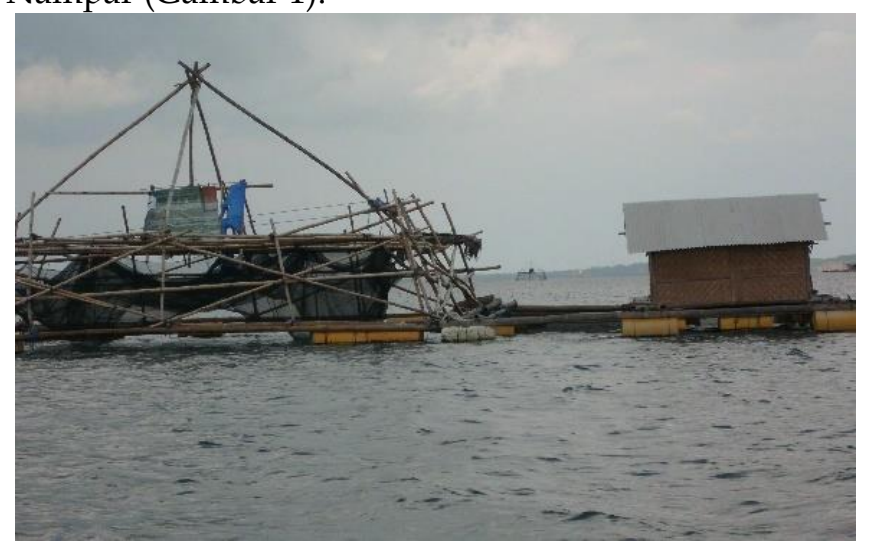

Gambar 1. Pengadaan KJA dan Bagan Apung

Pelaksanaan pembangunan KJA dan bagan tersebut berlangsung kurang lebih 1 bulan. KJA terbuat dari rangka bambu petung dengan ukuran $12 \times 12 \mathrm{~m}$ dan terdiri 9 petak yang dilengkapi 9 buah waring dan rumah jaga. Sarana karamba jaring apung tersebut dapat digunakan untuk penampungan benih atau pendederan maupun budidaya pembesaran lobster.

Pembangunan bagan apung merupakan sarana penangkapan ikan rucah sebagai bahan pakan lobster, baik untuk kegiatan pendederan maupun untuk kegiatan pembesaran. Bagan apung merupakan bagunan yang terbuat dari bambu berbentuk persegi empat yang diikat pada pelampung yang terbuat dari drum plastik yang dibungkus dengan terpal sehingga bangunan bagan ini tetap mengapung dan berdiri kokoh di atas perairan, di mana pada bagian tengah dari bangunan tersebut dipasang jaring (waring).

Untuk meningkatan pengetahuan, keterampilan, teknologi dan manajemen pakan usaha budidaya lobster, maka dilakukan pelatihan terhadap kelompok masyarakat sasaran. Pelatihan dilaksanakan dengan menggunakan metode Pendidikan Orang Dewasa (POD) dengan penekanan pada model komunikasi dua 
arah dengan pola tukar menukar pengalaman, diskusi kelompok, dan demonstrasi yang dilaksanakan dalam bentuk klasikal. Sedangkan untuk meningkatkan pengetahuan psikomotorik sasaran dilaksanakan praktek secara mandiri di luar kelas. Pelatihan dilaksanakan di rumah pemilik UD Sari Laut, pada tanggal 29 Oktober 2012 dihadiri 15 orang peserta (Gambar 2).

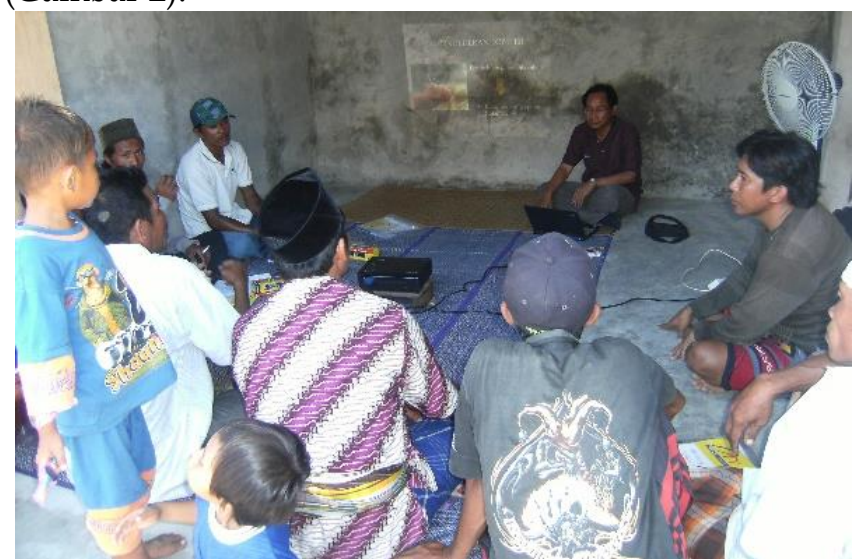

Gambar 2. Pelatihan Kelompok Pembudidaya Lobster Air Laut

Pembinaan yang dilakukan meliputi manajemen kelompok dan fasilitasi kemitran dengan pedagang pengumpulan atau eksportir serta pembinaan dalam teknologi pengemasan/pengepakan bibit lobster untuk dikirim pelanggan. Pengepakan benih lobster dilakukan dengan menggunakan kardus yang ditaburi pasir halus pada setiap tumbukan dan untuk membatasi setiap tumbukan diberikan kertas koran (Gambar 3). Teknik pengepakan mengguankan koran merupakan teknik yang pada umumnya digunakan oleh pembudidaya di Indonesia. Taqwa et al., (2013) melakukan penelitian pengepakan lobster menggunakan alang-alang dan hal tersebut dapat mengurangi resiko kematian setelah transportasi selama 48 jam.

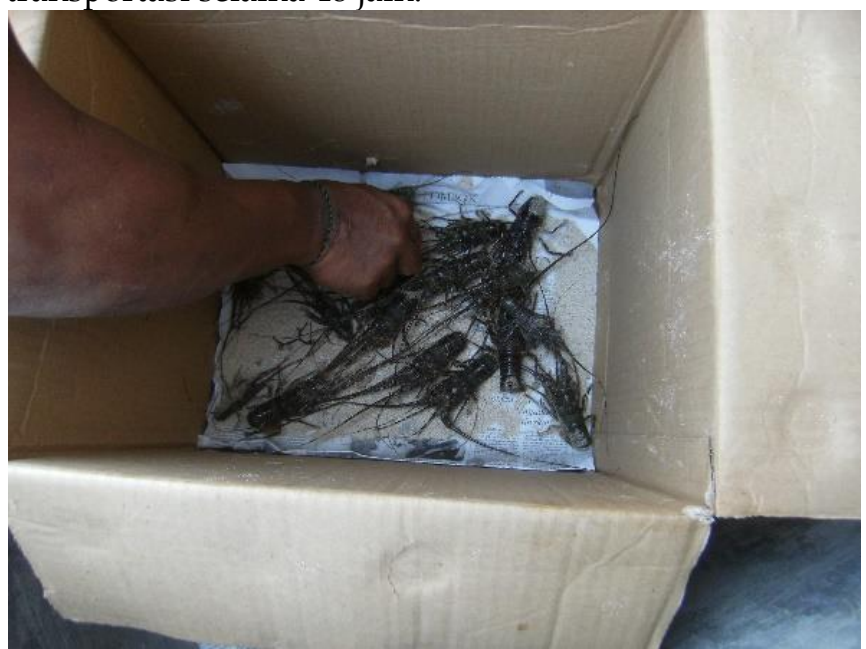

Gambar 3. Pengepakan Bibit Lobster
Monitoring dan evaluasi dilakukan dengan untuk memantau sampai sejauh mana keberhasilan pelaksanaan kegiatan yang dilakukan. Monitoring dilakukan oleh Tim Pelaksana IbM yang dilakukan setiap minggu selama pemeliharan lobster yang dilakukan dengan pengamatan tingkat kematian (mortalitas) dan pertumbuhan dan pengamatan operasional dan hasil tangkapan bagan (Gambar 4).
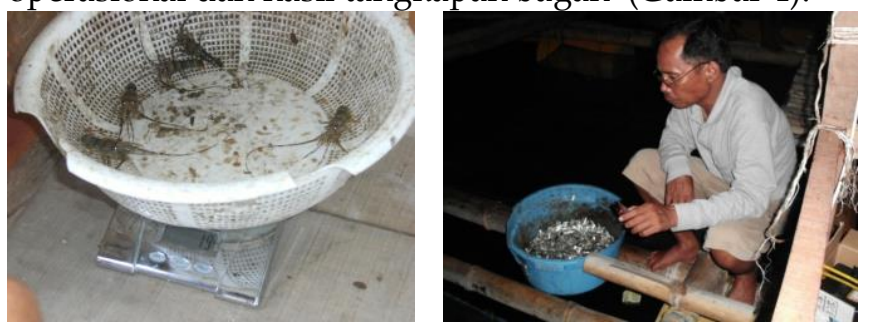

Gambar 4. Pengamatan Tingkat Kematian dan Pertumbuhan serta Pengamatan Operasional dan Hasil Tangkapan Bagan

Hasil monitoring tersebut kemudian dievaluasi apakah sesuai dengan target atau belum. Jika seandainya hasil evaluasi belum sesuai dengan target, maka dilakukan perbaikan seperlunya. Dalam kegiatan IbM ini diperoleh masalah tingginya biaya operasional bagan karena mahalnya harga minyak tanah sebagai BBM untuk lampu petromaks, dimana lampu petromaks ini digunakan sebagai alat bantu penangkapan ikan rucah. Penggunaan cahaya lampu dalam perikanan bagan berfungsi sebagai penarik bagi ikan-ikan yang bersifat fototaksis positif. Untuk mengatasi mahalnya harga minyak tanah, maka diadakan listrik tenaga surya (solar cell) (Gambar 5). Fauziayah et al., (2012) menjelaskan bahwa respon ikan lebih tinggi terhadap cahaya yang diberikan pada bagan tangkap, sehingga hasil tangkapan dapat optimal.

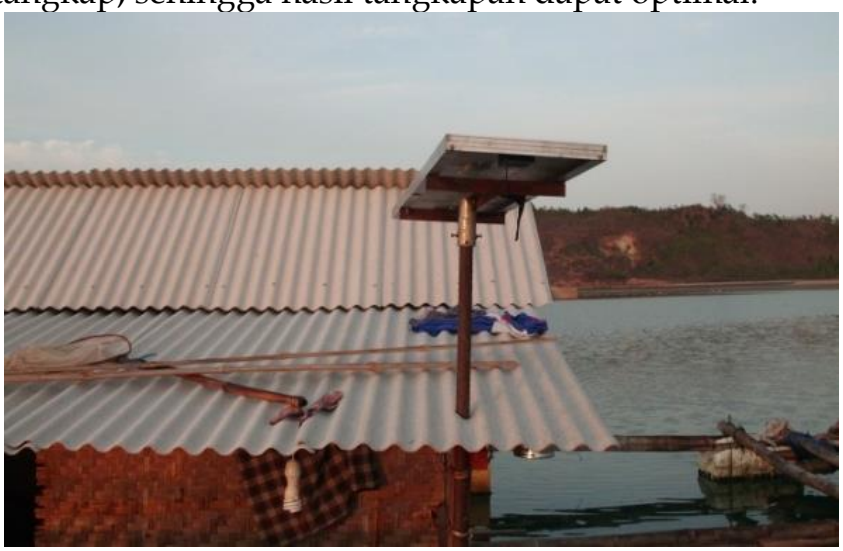

Gambar 5. Pengadaan Listrik Tenaga Surya

Hasil kegiatan pengadaan atau penambahan petak KJA menjadi 9 petak yang sebelumnya hanya 6 petak memberikan nilai positif bagi UD Sari Laut. Selain dapat menampung sekitar 1.350 ekor benih lobster, dengan penambahan petak KJA juga dapat dimanfaatkan untuk kegiatan pendederan benih dari 
benih yang masih transpan (putih). Waktu pendederan selama 1 bulan, pertumbuhan benih dari 1-2 g/ekor dapat berkembang menjadi 6-7 g/ekor. Harga jual benih transpan Rp. 5.000/ekor sementara yang berukuran berat 6-7 g/ekor mencapai Rp. 9.000/ekor, berarti ada selisih Rp.4.000/ekor. Kalau dihitung secara keseluruhan, katakanlah dari 9 petak KJA digunakan untuk pendederan benih dapat menampung 1.350 ekor, kemudian berdasarkan pengamatan di lapangan tingkat kematian (mortalitas) 20\% atau kelangsungan hidup (survival) mencapai 80\%. Dengan demikian keuntungan yang bisa diperoleh jika dilakukan usaha pendederan adalah sebesar Rp. 2.970.000/bulan. Namun hal ini belum bisa dilakukan karena ketersediaan benih tergantung musim dan kondisi alam lainnya.

Sampai saat ini belum ada usaha pembenihan lobster air laut yang berhasil menghasilkan benih untuk memenuhi kebutuhan usaha budidaya. Kendala yang dihadapi pada usaha pembenihan lobster yaitu waktu atau perkembangan dari stadia larva menjadi juvenil sangat lama, yaitu sekitar 6 bulan (Phillips and Cobs, 1980 dan Kittaka, 1997 diacu dalam Setyono, (2006); Minami et al., (2001). Percobaan yang dilakukan oleh Junaidi et al., (2011) di UPT Bio Industri Laut LIPI Lombok belum mampu melewati masa/stadia larva tersebut. Priyambodo (2009) juga menjelaskan bahwa usaha budidaya lobster di Kabupaten Lombok Timur sampai saat ini masih mengandalkan pada stok benih dari alam.

Hasil kegiatan pengadaan bagan apung untuk penangkapan ikan rucah untuk memenuhi kebutuhan pakan budidaya pembesaran lobster dalam KJA memberikan nilai positif bagi KUB Cinta Bahari. Dimana sebelum memiliki bagan apung, para pembudidaya biasanya memberi ikan rucah pada nelayan-nelayan di sekitar lokasi. Biaya untuk membeli ikan rucah berkisar antara Rp. 30.000 - Rp 50.000, tergantung pada musim maupun skala usaha. Dengan demikian dengan beroperasinya bagan apung tersebut, biaya produksi dari pakan dapat ditekan. Disamping itu, adanya bagan apung ini memberikan penghasilan tambahan, dimana ikan-ikan yang memiliki nilai komersial tinggi dijual ke pasaran. Penghasilan tambahan tersebut berkisar antara Rp. 50.000 - Rp. 70.000/hari.

Berdasarkan penelitian Sudirman et al., (2011) bagan memiliki 27 jenis ikan-ikan hasil tangkapan. Ikan hasil tangkapan tersebut digolongkan menjadi tiga macam. Tangkapan utama (primary catch). Tangkapan utama adalah tangkapan yang dipasarkan oleh nelayan karena memiliki nilai ekonomis yang tinggi,seperti jenis ikan tembang, teri, kembung, cumi-cumi, biji nangka dan lain-lain. Tangkapan sampingan (by catch), seperti jenis-jenis ikan peperek, dikeringkan lalu dijual sebagai bahan baku makanan ternak, sebagian lagi dibawa oleh nelayan kerumahnya sebagai lauk pauk untuk keluarganya. Tangkapan lainnya adalah tangkapan buangan (discard catch). Ikan-ikan tersebut biasanya dibuang ke laut. Jenis-jenis ikan yang tergolong discard pada bagan tancap adalah jenis-jenis buntal dan uburubur.

\section{Kesimpulan}

Hasil kegiatan IbM memberikan nilai posisitf bagi masyarakat sasaran, dengan bertambahnya unit keramba jaring apung untuk penampungan dan pendederan benih lobster dan tersedianya karamba bagan apung sebagai alat penangkapan ikan rucah untuk pakan dalam pemeliharaan lobster, maka akan memberikankan penghasilan tambahan baik melalui usaha pendederan lobster maupun penangkapan ikan komersial dari bagan.

\section{Ucapan Terima Kasih}

Ucapan terima kasih disampaikan kepada Kemenristek Dikti yang telah mendanai kegiatan ini melalui skim pendanaan Ipteks Bagi Masyarakat tahun anggaran 2012.

\section{Daftar Pustaka}

Cokrowati, N., Nur, D., Diniarti, N., Mukhlis, A., Amiri, M., \& Perwitasari, W. K. (2020). Pembuatan Pakan Pellet Moist Berbahan Baku Lokal Untuk Budidaya Lobster di Karamba Jaring Apung. Jurnal Pengabdian Magister Pendidikan IPA, 3(1), 2-6. https://doi.org/10.29303/jpmpi.v3i1.422

Fauziayah, Khairul Saleh, Hadi, dan F. S. (2012). Respon Perbedaan Intensitas Cahaya Lampu Petromak Terhadap Hasil Tangkapan Bagan Tancap Di Perairan Sungsang Sumatera Selatan. Maspari Journal, 4(2), 215-224.

Junaidi, M., Cokrowati, N., \& Abidin, Z. (2011). Tingkah Laku Induk Betina Selama Proses Pengeraman Telur dan Perkembangan Larva Lobster Pasir ( Panulirus homarus Linneaus, 1785 ). Jurnal Akuatika, 2(1), 1-10.

Minami, H., Nariaki Inoue, and Hideo, S. (2001). Vertical Distributions of Phyllosoma Larvae of Palinurid and Scyllarid Lobsters in the Western North Pacific. Journal of Oceanography, 57, 743-748.

Makasangkil, L., Indra R.N., dan Salindeho, C. L. (2017). Pengaruh Perbedaan Jenis Pakan Terhadap Pertumbuhan Lobster laut, Panulirus versicolor. Budidaya Perairan, 5(3), 1-10.

Priyambodo, 2009. Lobster Aquaculture Industry in Eastern Indonesia: Present Status and prospects. Proceedings of an International Symposium Spiny 
Lobster Aquaculture in the Asia-Pacific Region Nha Trang, Vietnam, 9-10 December 2008. Kevin C. Williams (Editor), ACIAR Proceedings 132. Australian Centre for International Agricultural Research. Canberra. Pp. 36-45.

Setyono, D. E. D. (2006). Budidaya Pembesaran Udang Karang (Panulirus spp.). Oseana, XXXI(4), 39-48.

Sudirman, Abdul Rahim Hade, dan Saprudin. (2011). Perbaikan Tingkat Keramahan Lingkungan Alat Tangkap Bagan Tancap Melalui Perbaikan Selktivitas Mata Jaring. Bulletin Penelitian LP2M Universitas Hasanuddin. II (1).

Susanti, E.N., Rina Oktaviani, Sri Hartoyo, dan Dominicus, S. P. (2017). Efisisensi Teknis Usaha Pembesaran Lobster Di Pulau Lombok Nusa Tenggara Barat. Jurnal Manajemen \& Agribisnis, 14(3), 230-239. https://doi.org//DOI: http://dx.doi.org/10.17358/jma.14.3.230

Taqwa, F.H., Yulisman, dan I. S. Y. (2013). Pemanfaatan Alang-alang Segar Pada Berbagai Lama Waktu Transportasi Sistem Kering Bertingkat Untuk Induk Lobster Air Tawar. JPHPI. 17 (3), 197-206. 